\title{
The Importance of Standardizing the Mapping of Surface Mining Operations for the Purpose of Minimizing Errors and Impacts on the Environment
}

\author{
Kamil Kyšel'a ${ }^{1}$, Peter Blišťan', Ol'ga Végsöová2* \\ ${ }^{1}$ Institute of Geodesy, Cartography and Geographical Information Systems, BERG Faculty, \\ Technical University of Kosice, Park Komenskeho 19, 04200 Kosice, Slovakia \\ ${ }^{2}$ Institute of Earth Resources, BERG Faculty, Technical University of Kosice, \\ Park Komenskeho 19, 04200 Kosice, Slovakia
}

Received: 5 April 2020

Accepted: 16 July2020

\begin{abstract}
This paper presents a comprehensive view of mine surveying and proposes standards of how to address this issue. The problem is related to the worn-out system for creating mining mapwork, which no longer meets the requirements of the present age. The aim of the research is to devise and propose a new functional system of standardization of map works (STAMAP) for the needs of the practice and the environment, which is being developed at FBERG. The creation of mine surveying documentation contains information relating to the environment and therefore it is necessary to harmonize the creation of a specific group of spatial information with current European legislation represented by the INSPIRE directive. The new system developed, STAMAP, uses a new classification of map symbols, the CMY (Cyan, Magenta, Yellow) colour scale and systematization of graphic files. The paper also includes practical and functional verification of the usability/functionality of the proposed standards using the example of creating digital mine surveying documentation for the Brestov quarry. The new scientific approach for standardizing map work, the STAMAP system, has up to $50 \%$ better results in terms of creating and identifying mine surveying documentation compared to the current situation.
\end{abstract}

Keywords: STAMAP system, mapping, mine mapping work, environment, research mapping systems

\section{Introduction}

Biological diversity (biodiversity) is the variety of all forms of life and their mutual interaction on Earth.

*e-mail: olga.vegsoova@tuke.sk
It includes ecosystems, habitats, species of plants, animals, microorganisms and the variability of genes and their interactions. Chrabaszcz et al. state that the preservation of biodiversity is the most important task of human endeavour during the entire course of mining; its protection and sustainability is the main objective in the process of mapping the mining operation [1-3]. 
The goods and services that biodiversity provides through healthy ecosystems are vital for maintaining well-being and for future economic and social development. In protecting the environment, the main emphasis must be placed on the surface and underground water that keeps the whole ecosystem alive and using the accurate monitoring of mining operations creating a complete view of the problems and also to protect forests and the atmosphere in the areas where there are mining operations [4-8].

Dong et al., state that the ecosystem of mining operations and the surrounding area is a very important element of the landscape and it is the location of a variety of forms of ecosystem services - these are benefits and uses provided by ecosystems, in this case the raw material in which a particular mining operation is rich [9]. Efficient and maximally costbeneficial mineral extraction is the essential interest of mining activity. Precise targeting and documentation of the mining operation aid in proposing the opening of an additional quarry, but it is also by calculating deposits and monitoring the use of deposits that we can determine economically and ecologically balanced exploitation [10]. According to Kays et al., considering the dramatic pace of change in our planet we need to quickly collect environmental data so we can document how nature is coming to terms with human interventions and so we can assess the impact of our interventions on protecting nature [11].

In the process of documenting the real state, objects are largely replaced by simplified 3D models. During the acquisition of spatial data using geodetic methods, these models are created using a series of measured point elements that are determined through a bound (connected to the geodetic framework), or a locally selected coordinate system with the coordinates $x$, $y, z$. Bak et al. claim that there are several surveying methods used in mine surveying activities which enable the mining surveyor to get a fair idea of the studied mining works [12-14]. The current state of science and technology is the basis for using these surveying procedures, methods and tools that result from an effort to rationalize measurement procedures by using the latest equipment and facilities [15-19]. Jaafar et al. say that the big problem of mine surveying activity has long been the lack of legislation across the EU; it is outdated and not adapted to the new trends and possibilities of our time and it also does not reflect the position of Europe as historically an important mining area [20]. The main objective of this paper is to unify and define the rules for creating mine surveying documentation, especially the graphical part, by defining rules which describe the creation of mine surveying documentation, however particularly basic mining maps, surface maps and special-purpose maps in digital form. The graphical part of mine surveying documentation should be drawn up in the CAD and GIS graphic environments [21-25]. Fulfilling this objective requires an assessment of the geodetic methods and a complete view of the current legislation in the field of mine surveying. The focus is on the benefit of the Decree of the Ministry of Economy of the Slovak Republic no. 1/1993 on mine surveying documentation and certain activities conducted using mining methods. It is necessary to supplement the binding regulations with new rules based on modern views on the issues under consideration. Then we

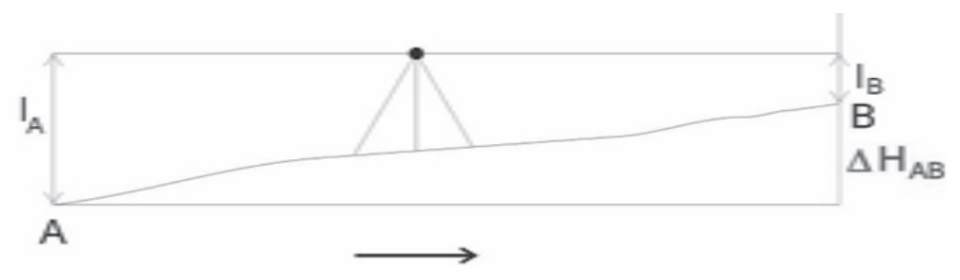

Fig. 1. Geodetic measuring methods [30].
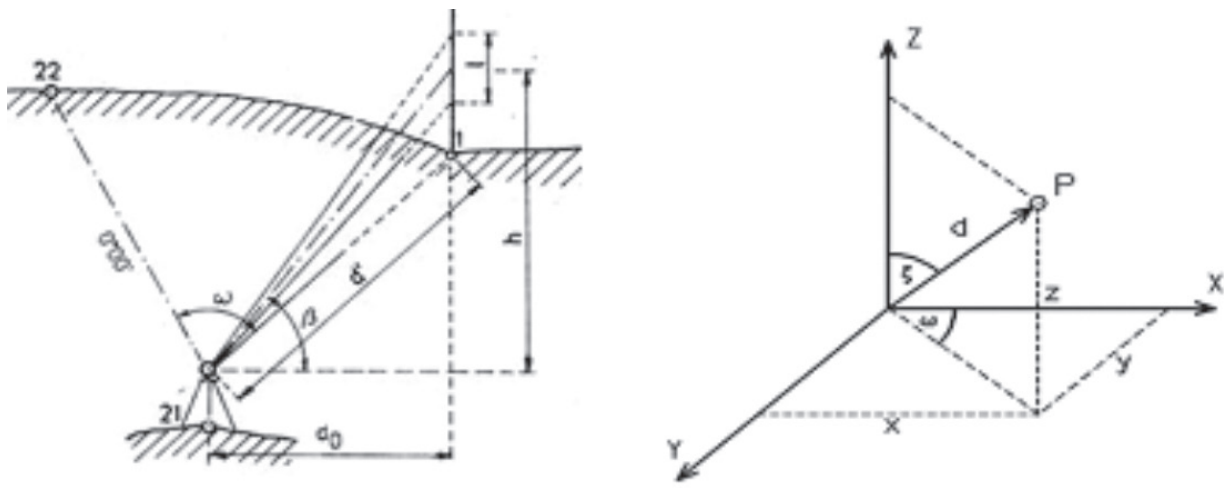

Fig. 2. Tachymetry and TLS [30]. 
will focus on field research and data collection, and the processing and creation of mine-surveying documentation in digital form in the context of the valid legislation on mine-surveying documentation and certain activities conducted using mining methods [26-29].

\section{Methodology}

Geodetic methods and procedures for creating copies of documents used in the mapping of surface mining operations can be divided based on the method of data collection into two categories:

a) direct methods:

- contact (levelling, tachymetry, GNSS),

- Non-contact (laser scanning, radar, photogrammetry, remote surveying of the earth).

b) indirect methods (e.g. digitization, measurement from auxiliary measurement baselines) [30].

Documentation is drawn based on the coordinate system of the Uniform Trigonometric Cadastral Network (abbreviation: $S$ - JTSK). S - JTSK is characterized by:

a) A Bessel ellipsoid with parameters:

$a=6377397.15508 \mathrm{~m}, \mathrm{~b}=6356078.96290 \mathrm{~m}, \mathrm{f}=$ 1: 299.152812853, where $a$ is the length of the major axis, $b$ is the length of the minor axis and $f$ is the flattening;

b) Křovák's Conformal Conic projection for general location.

Křovák's projection describes the calculation of the right-angled rectangular plane coordinates of the conformal conic projection for the general location of the given geographical coordinates on the Bessel ellipsoid of 1841. The constants arising from projecting the axes of Křovák's projection are $\varphi 0=49$ o 30', $\lambda=42$ o 30' $\alpha=1.000597498372, k=1.003419164$, $a=30$ o $17^{\prime} 17.30311^{\prime \prime}, \mathrm{k} l=0.9999$ and $\check{S} 0=78$ o 30 ", where " $\varphi 0$ " is the latitude of the undistorted base parallel on the Bessel ellipsoid. " $\lambda$ " is the geographic

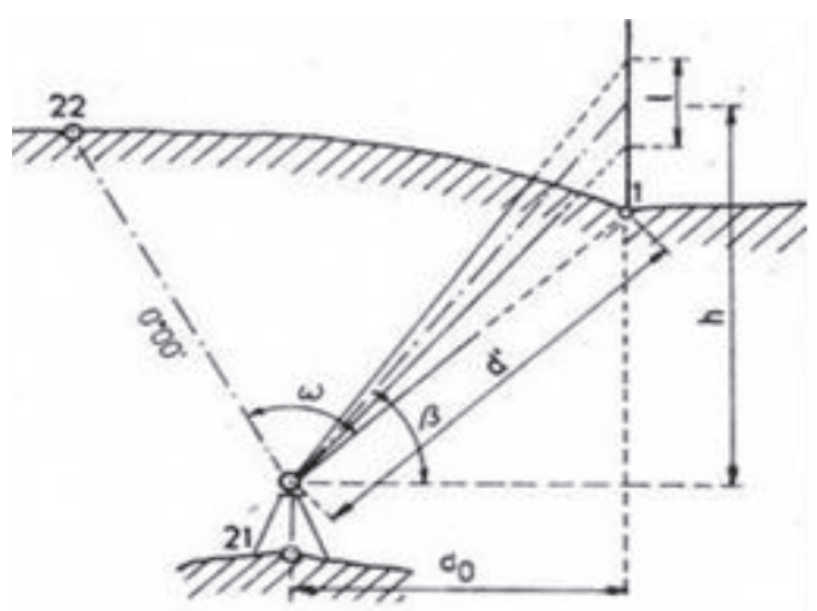

Fig. 3. Bessel ellipsoid [30]. length of the cartographic field on the Bessel ellipsoid defined on the Ferro base meridian," $\alpha$ " and " $k$ " are parameters characterizing the conformal Bessel ellipsoid on the spherical surface, " $a$ " is the field distance of the cartographic field on the spherical surface," $k 1$ " is the coefficient of reduction of the spherical surface and " $\breve{S} 0$ " is the width of the basic cartographic spherical surface.

Altitudes are given in the Baltic height system after adjustment. The Baltic height system after adjustment based on the vertical datum reference point of the average level of the sea water gauge in Kronstadt (Russia) is used as the set of standard altitudes in the international levelling networks of Eastern European countries.

The permitted tolerance in the position of points in the basic mining positional field is determined by two independent surveying methods and may not exceed $P_{O}= \pm 6 \times 10^{-2}(\mathrm{~m})$. The accuracy of the position of points on the basic mining position point field determined by the polygonal projection are assessed based on the achieved deviation in the direction of the last measured side and the achieved deviation in the position of the final point of the projection.

The achieved deviation (1) in the position of the end point may not exceed

$$
\mathrm{D}_{\mathrm{xy}}= \pm 10^{-3} \sqrt{k_{1} L+k_{2}[R R]}(\mathrm{m})
$$

...where $k_{1}=8, k_{2}=0.04$.

$L$ is the sum of the lengths of the measured sides of the polygonal projection in metres [RR] is the sum of the squares of the direct distances of individual points of the polygon projection from the final point of the projection in metres [31-32].

\section{Research}

The dimensions and map grids on a large scale and the dimensions of the large grid Basic Map of the Slovak Republic are derived from the dimensions of the triangulation sheets. The grid of map sheets is rectangular, determined using parallels with the $\mathrm{X}$ and $\mathrm{Y}$ axes of the projection system. By splitting the triangulation sheet into 4 columns and 5 layers, a map sheet is formed on a scale of 1:5000 with dimensions $2500 \times 2000 \mathrm{~m}$ (on a map of $500 \times 400 \mathrm{~mm}$ ). By dividing the map sheet of 1:5000 into 2 columns and 2 layers a map sheet is formed with a scale of 1:2000 with dimensions of $1250 \times 1000 \mathrm{~m}$ (on a map of $625 \times 500 \mathrm{~mm}$ ). Also, by dividing the map sheets into quarters, more map sheets are derived on larger scales such as 1:1000, 1:500. The following will describe the selected surveying methods used to collect spatial data - planimetric and elevation data for the needs of mapping and spatial modelling of surface mining operations. 
Table 1. Dimensions of map sheets.

\begin{tabular}{|c|c|c|c|}
\hline Map scale & $\begin{array}{c}\text { Dimension of the frame of the map sheet } \\
{[\mathrm{mm}]}\end{array}$ & $\begin{array}{c}\text { Dimensions of the displayed area } \\
{[\mathrm{m}]}\end{array}$ & $\begin{array}{c}\text { Area of the displayed area } \\
{[\mathrm{H}]}\end{array}$ \\
\hline $1: 5000$ & $500 \times 400$ & $2500 \times 2000$ & 500 \\
\hline $1: 2000$ & $625 \times 500$ & $1250 \times 1000$ & 125 \\
\hline $1: 1000$ & $625 \times 500$ & $625 \times 500$ & 31.25 \\
\hline
\end{tabular}

Table 2. Example of the markings of the map sheets.

\begin{tabular}{|c|c|}
\hline Map scale & On the map sheet \\
\hline $1: 5000$ & Košice $2-7$ \\
\hline $1: 2000$ & Košice $2-7 / 1$ \\
\hline $1: 1000$ & Košice $2-7 / 21$ \\
\hline
\end{tabular}

In creating, maintaining or restoring the graphical part of mine surveying documentation, we follow the Decree of the Economy Ministry of the Slovak Republic no. 1/1993 and STN 013411 Map Symbols, which specifies the drawing and positioning of symbols, orientation of symbols and their colouring.

The digital processing of documentation and integrating content into individual layers gains us another dimension for simpler maintenance, renewal and use of the map data.

For the presentation of information, the following will be used depending on the scale and type of graphical documentation and mapping generalization being produced [32-34]:

a) simplifying the contours and shapes of the displayed objects,

b) representing of objects or phenomena symbolically,

c) combining the methods mentioned under a) and b).

Objects, the image of which on a scale of 1:2000 and greater exceed the smallest dimension of the drawing are displayed based on the measured data (with possible simplification), sometimes by drawing the appropriate symbol in the displayed object.

Objects, the image of which on the given scale is less than or equal to the smallest dimension of the drawing are in principle displayed with a symbol. The smallest dimension in this case is considered to be objects, rooms, structures and equipment with a simple floor plan where the shortest side of the drawing is $2 \mathrm{~mm}$. The smallest dimension for detailed shapes is also considered to be $1 \mathrm{~mm}$. The thickness of nondimensioned lines is $0.18 \mathrm{~mm}$. The variation in the size of a symbol may not be greater than $0.5 \mathrm{~mm}$. If the points of the point field are located on structures, the symbol of the point is connected with the depiction of the structure. The positional location of the symbol may not be distorted. Symbols which label the footprints of objects are oriented depending on the situation (e.g. mouth of a tunnel). Other symbols and their description are oriented based on the frame of the graphical documentation. The description of the symbol is usually to the right of the symbol.

Digital processing and documentation after integrating content into each layer offers another dimension for easier, maintenance, renewal and use of maps.

By setting uniform colours of drawing keys, symbols and descriptions we get fully functional and transparent sketches, ZBM, surface maps, utility maps mining and profiles, sections, surface maps, and single-purpose

Table 3. Technicolor colour scale.

\begin{tabular}{|c|c|c|c|c|}
\hline $\begin{array}{c}\text { Colour } \\
\text { code }\end{array}$ & Colour & \multicolumn{2}{|c|}{ CMY colour model } & Code \\
\hline 1 & white & $0,0,0$ & T1 \\
\hline 2 & chrome yellow & $0,0,255$ & T3 \\
\hline 3 & orange & $0,102,255$ & T4 \\
\hline 4 & vermillion & $0,204,255$ & T5 \\
\hline 5 & carmine & $90,255,222$ & T6 \\
\hline 6 & karmazin & $51,255,255$ & T7 \\
\hline 7 & purple red & $41,255,108$ & T8 \\
\hline 8 & bluish purple & $102,204,0$ & T9 \\
\hline 9 & purple & $0,255,0$ & T28 \\
\hline 10 & light blue & $205,105,0$ & T10 \\
\hline 11 & ultramarine dark & $255,204,51$ & T11 \\
\hline 12 & Prussian blue & $255,255,102$ & T12 \\
\hline 13 & Berlin blue & $255,255,0$ & T27 \\
\hline 14 & indigo & $204,204,51$ & T13 \\
\hline 15 & viridiana & $255,102,102$ & T14 \\
\hline 16 & light green & $255,0,255$ & T29 \\
\hline 17 & leaf green & $255,102,255$ & T16 \\
\hline 18 & brown ochre & $102,153,204$ & T18 \\
\hline 19 & burnt sienna & $102,204,255$ & T19 \\
\hline 20 & reddish brown & $102,217,255$ & T21 \\
\hline 21 & natural sepia & $51,153,255$ & T22 \\
\hline 22 & light grey & $63,63,63$ & T25 \\
\hline 23 & dark grey & $160,160,160$ & T23 \\
\hline 24 & black & $255,255,255$ & T24 & \\
\hline
\end{tabular}


maps. A wide range of colours for drawing keys and symbols enable detailed presentation of the graphical part with which we can identify the kind of utility lines that there are, the material or dimension that was used in building, or in the case of a point element which is assigned a symbol, we just identify what the object in question is.

The factual situation will be presented, depending on the scale and type of graphic documentation, using mapping generalization, by:

a) simplifying the contours and shape of the displayed objects,

b) representation of objects or phenomena symbolically - with a symbol,

c) a combination of the methods mentioned under a) and $b$ ).

In the event that the drawings overlap or there is decreased readability and clarity of the graphical documentation, the description of the symbol is placed in another suitable place. Description of long objects and linear constructions is done parallel to the longer dimension [31-33].

The dimensions of symbols correspond to their use in graphical documentation on a scale of 1:1000 or 1:2000. On a scale of 1:500, the dimensions of the symbols are doubled. In graphical documentation on a scale of 1:5000 and smaller, the dimensions of the symbols are shrunk by half. Symbols are drawn in black. In the case of the use of other colours, $t$ he Technicolor scale is used [32]. The Technicolor colour table is designed using a colour scale which contains 24 colours so that each colour is assigned a label from $\mathrm{T} 1$ to $\mathrm{T} 24$. The colour model used is the CMY model. 24 colours are used in the Technicolor scale for the purpose of easy orientation with a smaller number and in order to take into account the act that there were 24 original Technicolor colours.
Table 5. Comparison of STAMAP and previously used rules.

\begin{tabular}{|c|c|c|}
\hline & STAMAP & Previous state \\
\hline Symbol & 1 & 1 \\
\hline Classification of symbols & 1 & 0 \\
\hline Summary of symbols & 1 & 0 \\
\hline Colours & 1 & 0 \\
\hline Colour scale & 1 & 0 \\
\hline CMY colour model & 1 & 0 \\
\hline GS structure & 1 & 0 \\
\hline GS systemization & 1 & 0 \\
\hline ML dimensions & 1 & 1 \\
\hline ML scale & 1 & 1 \\
\hline RESULT & 10 & 5 \\
\hline
\end{tabular}

The graphical data is the graphical part of mine surveying documentation and it is divided into separate files (drawings) in the *.dgn format. The drawing part of the graphical part of mine surveying documentation can be done in analogue or in digital form.

For each file basic objects are defined, including all basic properties (attributes). The file name should be based on the identifying code of the mining operation (BP), an underscore and the content specification of the file.

The full file name has the form BP_xxxxx.dgn where:

BP is the code for the territorial unit to which the drawing refers; $\operatorname{xxxxx}$ is the name of the file characterizing the data contained in the file based on

Table 4. Structure of graphic files for mine surveying documentation.

\begin{tabular}{|c|c|c|}
\hline File name & Shortcut File & Contents \\
\hline BP_bodpole.dgn & $\mathrm{BP}$ & $\begin{array}{l}\text { ŠPS, ŠTS, PPBP, ŠNS points used for the staking out structures, point number, height } \\
\text { of point, connectors of the point. }\end{array}$ \\
\hline BP_podrbod.dgn & PL & Detailed points, symbol of point, height of point. \\
\hline BP_polohopis.dgn & PP & $\begin{array}{c}\text { Full mining situation, equipment and buildings located within } 100 \text { metres of the } \\
\text { boundary of the mining area. }\end{array}$ \\
\hline BP_vyskopis.dgn & IN P & Contours, hatches and elevation markings. \\
\hline BP_inzsiete.dgn & IS & $\begin{array}{l}\text { Water pipe, equipment and structures for water pipes, sewer pipes, equipment and } \\
\text { structures for sewer pipes, gas pipes, equipment and structures for gas pipes, power } \\
\text { lines, equipment and structures for power lines. }\end{array}$ \\
\hline BP_kataster.dgn & $\mathrm{KN}$ & The name and boundaries of the land registry area, parcel number. \\
\hline BP_maplist.dgn & ML & Series of map sheets, hectometre grid network, information out of frame. \\
\hline BP_nacrtbod.dgn & NB & Clear sketch of the positional point field. \\
\hline BP_geodbod.dgn & GU & Geodetic data on points in the positional field. \\
\hline BP_ortofoto.dgn & $\mathrm{OM}$ & Digital orthophotomap. \\
\hline
\end{tabular}


the structure defined for the graphical part of mine surveying documentation (see Table 4).
All *.dgn files that are part of the Annex serve as a model for creating ZBM, surface maps, and special-

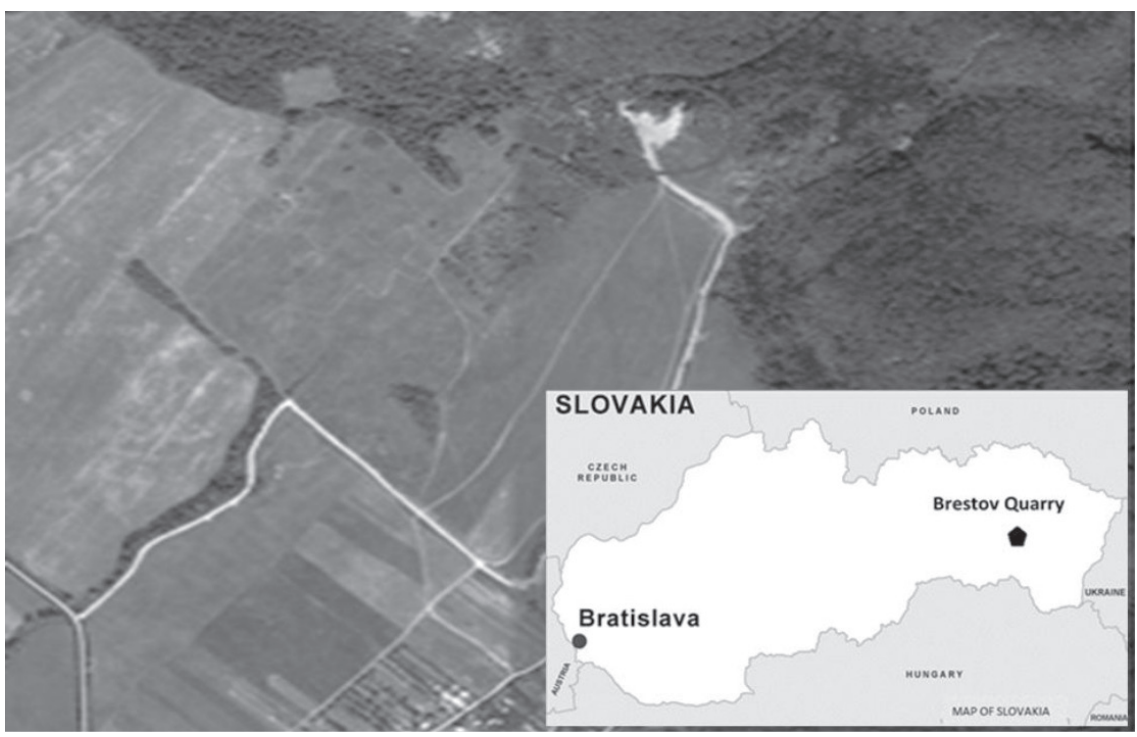

Fig. 4. Brestov Quarry.
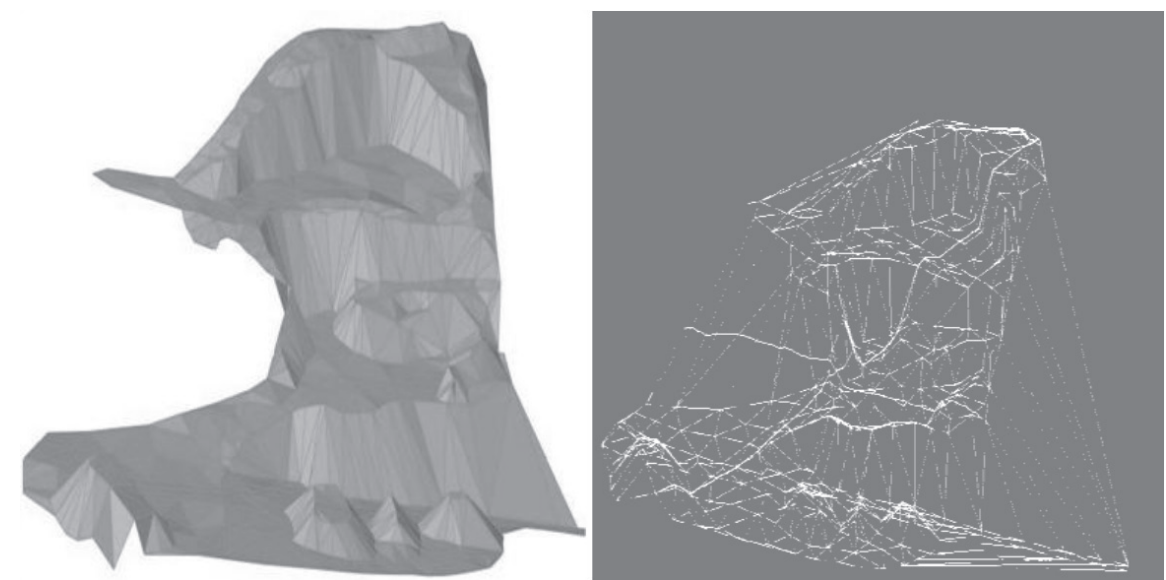

Fig. 5. 3D Model of Brestov Quarry.

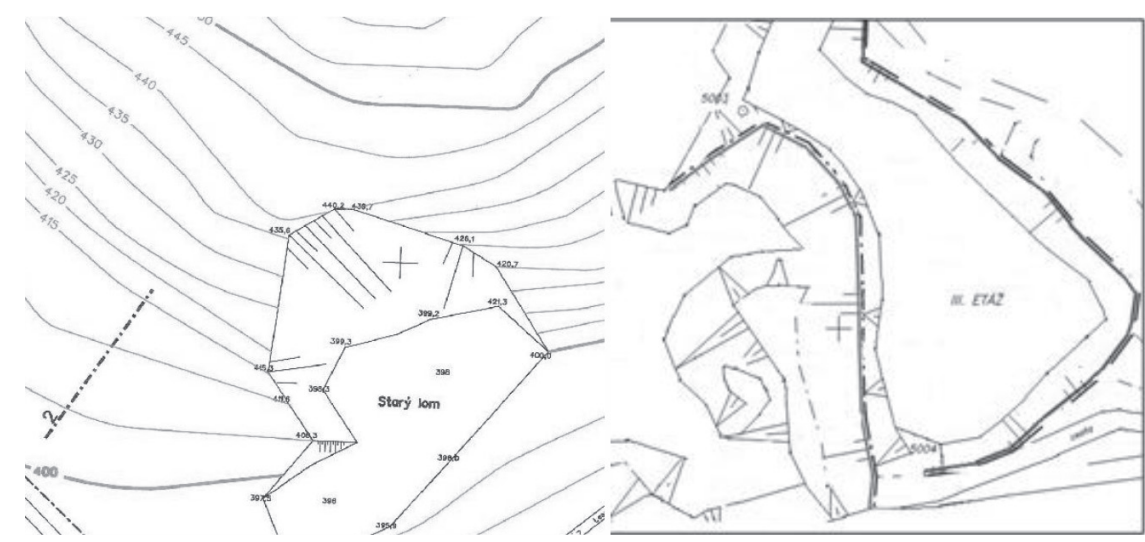

Fig. 6. Comparison of original mine surveying documentation and mine surveying documentation created in the proposed STAMAP system. 
purpose maps. *.dgn files contain a predefined library of cells and the colours in them are defined in terms of the Technicolor scale.

Comparing STAMAP and the previously used rules shows that the newly designed system got an overall score of 10 points, while the previously used rules only scored 5 points, showing that the STAMAP system has up to $50 \%$ better results than the previously used rules.

\section{Results and Discussion}

For the purpose of verifying the functionality of the proposed rules for creating mine surveying documentation in digital form, a survey was performed on the Brestov quarry and this data was them compiled into mine surveying documentation in digital form using the proposed methodological approach. The Brestov quarry is in the district of Prešov in Slovakia's Prešov Region. it is located in the village of Brestov in the Brestov land registry area. The Brestov andesite deposit is mined using surface techniques and it is located on the southwest side of the Slanské Hills in the Brestov land registry area. It lies at a distance of $1 \mathrm{~km}$ northeast of the built-up area of Brestov. The deposit is mined in a wall-type quarry using a mechanical method.

The MicroStation V8 CAD system and its TerraModeler included extension were used to process the measured and obtained data. Use was also made of the Groma application that can be launched directly from the program thereby interconnecting the data and graphical part.

Information from measuring points, as well as information from the digital data obtained were placed in layers based on the written rules of the STAMAP system. Modifications subsequently removed unnecessary, duplicate or erroneous points. The 3D model created contours in the first and second stage in the MicroStation V8 program. The basic mining map and a map of the surface were also created.

Despite this finding, the issue of effective and sufficiently precisely defined creation of mine surveying documentation is still current and in this particular area it is necessary to give attention to the following questions.

Is the defined method for solving the problem also suitable for aerial scanning? How would the structure of graphical DWG files look? Is it appropriate to use the RGB colour model?

\section{Conclusions}

The design and application of the new rules of the proposed STAMAP system, illustrated using the example of processing a map work for the Brestov Quarry, meets the requirement for a significant timesaving when creating this a map series. After testing, we proved that the STAMAP system gives up to $50 \%$ better results than the rules previously used for creating mine surveying documentation. The primary interest of every commercial company is to improve the efficiency of work, reduce costs and provide quality products [35-37]. These principles are also reflected in the creation of mine surveying documentation and especially in above proposals for the use of the colour table, the structure of graphic files, the dimensions of the map sheets and the definition of rules when working with the drawing keys. Map works made well in this way offer a basis for fast and accurate mapping of mining operations, which contributes to environmental protection. The creation of these rules is fully supported by the subsequent protection of surface and underground water, soil and air quality in accordance with the INSPIRE Directive which orders a high level protection in environmental policy, which requires objective spatial information in addition to formulation and implementation. It is necessary to establish coordination between the users and providers of information, which we have done by defining the rules mentioned above. Rules have been proposed to ensure that spatial data is stored, made available and maintained at the most appropriate level to be able to combine spatial data and use it for the benefit of the greatest environmental protection.

\section{Acknowledgements}

The submitted work is a part of the projects "Projects of applied research as a means for development of new models of education in the study program of industrial logistics" KEGA 016TUKE-4/2020 and the project "Research and development of new SMART solutions based on principles of the Industry 4.0, logistics, 3D modelling and simulation for production streamline in the mining and building industry" VEGA 1/0317/19.

\section{Conflict of Interest}

The authors declare no conflict of interest.

\section{References}

1. CHRABASZCZ M., MROZ L. Tree Bark, a valuable source of information on air quality. Polish Journal of Environmental Studies, 26 (2), 453, 2017. doi:10.15244/ pjoes $/ 65908$

2. KRAJNÍKOVÁ K., SMETANKOVÁ J., BEHÚNOVÁ A. Building sustainability and building information modelling. Acta Tecnología, 5 (1), 1, 2019. doi:10.22306/ atec.v5i1.45

3. SZOPIK-DEPCZYNSKA K., CHEBA K., BAK I., KIBAJANIAK M., SANIUK S., DEMBINSKA I., IOPPOLO G. The application of relative taxonomy to the study of disproportions in the area of sustainable development of 
the European Union. Land use policy, 68 (11), 481, 2017. doi:10.1016/j.landusepol.2017.08.013

4. FENG M., SEXTON J.O., CHANNAN S., TOWNSHEND J.R. A global, high-resolution (30-m) inland water body dataset for 2000: first results of a topographic-spectral classification algorithm. International Journal of Digital Earth, 9 (2), 113, 2016.

5. CHARYA T.D., LEE D.H., YANG I.T., LEE J.K. Identification of water bodies in a Landsat 8 OLI image using a J48 decision tree. Sensors, 16 (7), 1, 2016.

6. ÖZELKAN E., KARAMAN M. The analysis of the effect of meteorological and hydrological drought on dam lake via multitemporal satellite images: a case study in Atikhisar Dam Lake (Çanakkale). Omer Halisdemir University Journal of Engineering Sciences, 7 (2), 1023, 2018.

7. BUDAKOGLU M., UCA AVCI Z.D., ÖZELKAN E., BULBUL A., CIVAS M., TASDELEN S. Determination of seasonal changes in wetlands using CHRIS/Proba Hyperspectral satellite images: A case study from Acigöl (Denizli), Turkey. Journal of Environmental Biology, 36 (1), 73, 2015.

8. HE H., Li. X., LI X., CUI J., ZHANG W., XU W. Optimizing the DRASTIC Method for Nitrate Pollution in Groundwater Vulnerability Assessments: A Case Study in China. Polish Journal of Environmental Studies, 27 (1), 95, 2018.

9. DONG J.H, MENG L., BIAN Z., FANG A. Investigating the Characteristics, Evolution and Restoration Modes of Mining Area Ecosystems. Polish Journal of Environmental Studies, 28 (5), 3539, 2019.

10. WADE E.M. Environmental Economics \& the Mining Industry. Springer Science+ Business Media New York, 1994

11. KAYS R., MCSHEA W.J., MIELSKI M. Born-digital biodiversity data: Millions and billions. Diversity and Distributions, 26 (5), 644, 2020.

12. BARRY M., ASIEDU K. Visualising changing tenure relationships: the talking titler methodology, data mining and social network analysis, Survey Review, 49 (352), 66, 2017. doi:10.1080/00396265.2015.1120385

13. BĄK W., SOBIERAJ-ŻŁOBIŃSKA A. Standard deviation as the optimization criterion in the OptD method and its influence on the generated DTM. E3S Web of Conferences; 63, 2018. doi:10.1051/e3sconf/20186300011

14. STRAKA M., HRICKO M. Software system design for solution of effective material layout for the needs of production and logistics. Wireless Networks, 2020 (Feb), 1, 2020. doi: $10.1007 / \mathrm{s} 11276-020-02267-6$

15. COUTTS B.J., STRACK M.S. Is there still a (land) surveying profession?. Survey Review, 51 (366), 244, 2019. doi: $10.1080 / 00396265.2017 .1416730$

16. ÖZELKAN E. Water Body Detection Analysis Using NDWI Indices Derived from Landsat-8 OLI. Polish Journal of Environmental Studies, 29 (2), 1759, 2019. doi:10.15244/pjoes/110447

17. GALLAY M., KAŇUK J., HOCHMUTH Z., MENEELY J., HOFIERKA J., SEDLÁK V. Large-scale and highresolution $3 \mathrm{D}$ cave mapping by terrestrial laser scanning: a case study of the Domica Cave, Slovakia. International Journal of Speleology, 44 (3), 277, 2015.

18. RÜTHER H., CHAZAN M., SCHROEDER R., NEESER R., HELD C., WALKER S. J., MATMON A., KOLSKA HORWITZ L. Laser scanning for conservation and research of African cultural heritage sites: the case study of Wonderwerk Cave, South Africa. Journal of Archaeological Science, 36 (9), 1847, 2009.

19. STRAKA M., ROSOVA A., LENORT R., BESTA P, SADEROVA J. Principles of computer simulation design for the needs of improvement of the raw materials combined transport system. Acta Montanistica Slovaca, 23 (2), 163, 2018.

20. JAAFAR H.A., MENG X., SOWTER A. Terrestrial laser scanner error quantification for the purpose of monitoring. Survey Review, 50 (360), 232, 2018. doi:10.1080/00396265. 2016.1259721

21. KYŠELA K., BLIŠŤAN P., KOVANIČ L. Use of selected geodetic methods for surveying surface mining operations in order to create their 3D models. Fórum mladých geoinformatikov 2013, Technical University in Zvolen,, 2013 [In Slovak].

22. ARIF K., AFZAL Z., NADEEM M., Ahmad B., Mahmood A., Iqbal M., Nazir A. Role of Graph Theory to Facilitate Landscape Connectivity: Subdivision of a Harary Graph. Polish Journal of Environmental Studies, 27 (3), 993, 2018. doi:10.15244/pjoes/75961

23. CETIN M. Using GIS analysis to assess urban green space in terms of accessibility: case study in Kutahya. The International Journal of Sustainable Development and World Ecology, 22 (5), 1, 2015.

24. CETIN M. Sustainability of Urban Coastal Area Management: A Case Study on Cide. Journal of Sustainable forestry, 35 (7), 527, 2016.

25. GRABARA J., DABYLOVA M., ALIBEKOVA G. Impact of legal standards on logistics management in the context of sustainable development. Acta logistica, 7 (1), 31-37, 2020. doi:10.22306/al.v7i1.155

26. CETIN M., SEVIK H. Evaluating the recreation potential of Ilgaz Mountain National Park in Turkey. Environmental Monitoring and Assessment, 188 (1), 52, 2016.

27. MESÁROŠ P., MANDIČÁK T., MESÁROŠOVÁ A., BEHÚN M. Developing Managerial and Digital Competencies Trough BIM Technologies in Construction Industry. ICETA 2016, 217, 2016.

28. VEGSOOVA O., STRAKA M., SULOVEC V. Global Assessment of Industrial Expansion for Minimizing Environmental Impacts Utilizing the Principles of Mining and Logistics. Rocznik Ochrona Srodowiska, 21 (1), 14, 2019.

29. ČULKOVÁ K., TAUŠOVÁ M. Risk evaluation in energetic industry. Acta Tecnología, 5 (2), 43, 2019. doi:10.22306/ atec.v5i2.54

30. KYŠEL'A K., BAKALÁR T., PAVOLOVÁ H., BLIŠŤAN P., BOBÍKOVÁ D. Mapping of surface mining operations and creation of mining documentation in the territory of the Slovak Republic. Brno, EU Tribune, 2019.

31. STANĚK V., HOSTINOVÁ G., KOPÁČIK A. Geodesy in construction. JAGA GROUP Publishing House, s.r.o., 2007 [In Slovak].

32. Decree of the Office of Geodesy, Cartography and Cadaster of the Slovak Republic of 14 June 2009, which implements the Act of the National Council of the Slovak Republic No. 215/1995 Coll. on geodesy and cartography as amended, 2009 [In Slovak].

33. NEJEDLÝ M., BITTERER L. Geoportal, decimal scales, Available online: https://www.geoportal.sk/sk/katasternehnutelnosti/klady-mapovych-listov-velkychmierok/ dekadicke-mierky/ [02. Apr. 2020], 2015 [In Slovak].

34. TREBUNA P., STRAKA M., ROSOVA A., MALINDZAKOVA M., MAKYSOVA H. Design of 
colored Petri net models for streamlining of chemical production. Przemysl Chemiczny, 95 (7), 1300, 2016. doi:10.15199/62.2016.7.3

35. STRAKA M., TREBUNA P., ROSOVA A., MALINDZAKOVA, M., MAKYSOVA H. Simulation of the process for production of plastics films as a way to increase the competitiveness of the company. Przemysl Chemiczny, 95 (1), 37, 2016.
36. BOŽEK P., AL AKKAD M. A., BLIŠTAN P., IBRAHIM N.I. Navigation control and stability investigation of a mobile robot based on a hexacopter equipped with an integrated manipulator. International Journal of Advanced Robotic Systems, 14 (6), 1, 2017.

37. BESTA P., LAMPA M. Iron production logistic aspects. Acta logistica, 6 (4), 179, 2019. doi:10.22306/al.v6i4.147 
